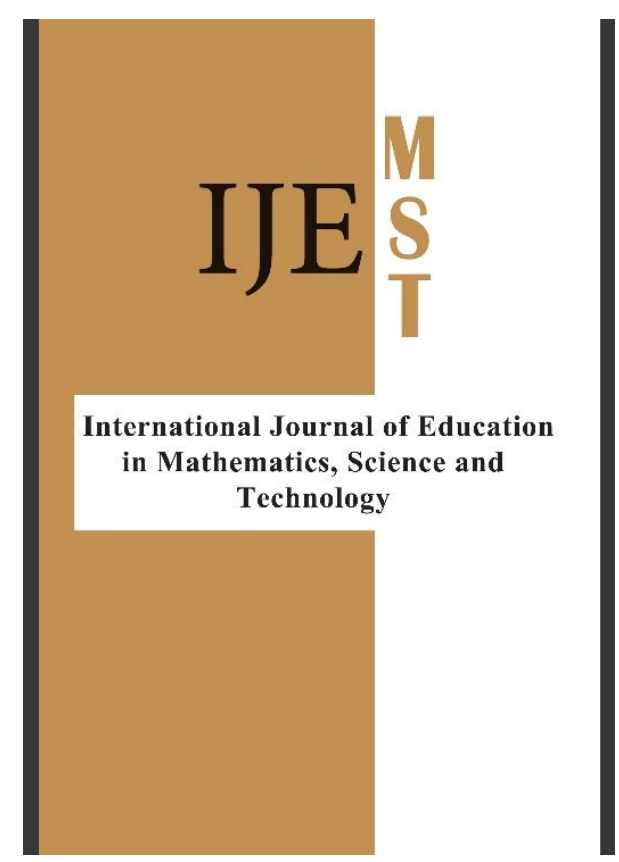

ISSN: $2147-611 \mathrm{X}$

\section{International Journal of Education in Mathematics, Science and Technology (IJEMST)}

\section{www.ijemst.com}

\section{From Deficit Thinking to Counter Storying: A Narrative Inquiry of Nontraditional Student Experience within Undergraduate Engineering Education}

\author{
Angela Minichiello \\ Utah State University
}

To cite this article:

Minichiello, A. (2018). From deficit thinking to counter storying: A narrative inquiry of nontraditional student experience in undergraduate engineering education. International Journal of Education in Mathematics, Science and Technology (IJEMST), 6(3), 266-284. DOI: $10.18404 /$ ijemst.428188

This article may be used for research, teaching, and private study purposes.

Any substantial or systematic reproduction, redistribution, reselling, loan, sub-licensing, systematic supply, or distribution in any form to anyone is expressly forbidden.

Authors alone are responsible for the contents of their articles. The journal owns the copyright of the articles.

The publisher shall not be liable for any loss, actions, claims, proceedings, demand, or costs or damages whatsoever or howsoever caused arising directly or indirectly in connection with or arising out of the use of the research material. 


\title{
From Deficit Thinking to Counter Storying: A Narrative Inquiry of Nontraditional Student Experience within Undergraduate Engineering Education
}

\author{
Angela Minichiello
}

\begin{tabular}{|c|c|}
\hline Article Info & Abstract \\
\hline Article History & $\begin{array}{l}\text { This paper reports on narrative inquiry research conducted with nontraditional } \\
\text { undergraduates as they pursued a common goal of becoming engineers. }\end{array}$ \\
\hline $\begin{array}{l}\text { Received: } \\
\text { 30 June } 2017\end{array}$ & $\begin{array}{l}\text { Participants were enrolled in a two-year engineering transfer program offered in } \\
\text { the evenings, via synchronous broadcast distance instruction, by a public, land- }\end{array}$ \\
\hline $\begin{array}{l}\text { Accepted: } \\
20 \text { December } 2017\end{array}$ & $\begin{array}{l}\text { grant university situated in the western United States. The purpose of the } \\
\text { research was to understand the experiences of nontraditional students during the } \\
\text { two-year program, which they accessed at regional campuses within or near their }\end{array}$ \\
\hline & $\begin{array}{l}\text { local communities, and later as they transitioned to the four-year university } \\
\text { campus located in another city away from these communities. In this paper, }\end{array}$ \\
\hline Adult learners & personal, social, and institutional tensions, arising from instances of deficit \\
\hline Broadening participation & thinking and emerging from within the participants' lived and told stories, are \\
\hline Dewey & identified and examined. Despite deep, personal reactions to the bias they \\
\hline $\begin{array}{l}\text { Engineering transfer } \\
\text { student }\end{array}$ & $\begin{array}{l}\text { experienced, participants overcame perceptions of personal deficiency to pursue } \\
\text { and achieve their goal of becoming engineers. Participant counter stories further } \\
\text { revealed ways in which their unique life experiences alternately served to } \\
\text { enhance and deepen their engineering education. }\end{array}$ \\
\hline
\end{tabular}

I know I have put myself in this situation, as far as being a nontraditional student, but it sure is tough trying to hang in there with the traditional students. I keep feeling like the instructors/advisors must think I am a terrible student and that engineering may not necessarily be what I should be pursuing. If I had a chance to explain my situation, that school is really my third (major) priority, maybe they would better understand my seemingly lackadaisical effort, when sometimes that effort is truly all I can give.

(Joe, reflecting on his interim research text, January 2016)

\section{Introduction}

Within the United States today, policymakers search for effective ways to expand the nation's engineering workforce while addressing underrepresentation in science, technology, engineering, and mathematics (STEM). Recent recommendations call for establishment of innovative programs capable of broadening STEM undergraduate participation in ways that include the talent residing within diverse student groups. Specifically, current federal policy guidance explicitly states that nontraditional students should be top priorities for STEM recruitment initiatives, degree programs, and interventions (President's Council of Advisors on Science and Technology (PCAST), 2012, p. vii). As a group, nontraditional students include older, working adults and others whose life circumstances differ markedly from those possessed by undergraduates who enter college directly after high school. Moreover, the United States is not alone in its concerns regarding the likelihood for engineer shortages; many countries of Europe, as well as other industrialized nations throughout the world, share unease regarding the resistance of today's youth to pursue engineering careers, high attrition rates among current engineering students, and sustained low enrollment of women in engineering (Becker, 2010, p. 349; Morice, 1990). Thus, efforts made toward building in-depth understanding of nontraditional student participation, achievement, and retention in STEM may be considered widely relevant across a global landscape.

The purpose of this research is to examine the lived experience of a group of nontraditional students who participated in a distance-delivered, undergraduate engineering transfer program. Offered from 2009-2016 by a 
mid-size, public, land grant institution situated in the western United States, the program aimed to improve participation of geographically dispersed, rural, and/or working residents located throughout the state by providing access to the first two-years of engineering education within (or close to) residents' local communities. The current study, part of a larger project focused on developing a deeper understanding of the experience of success among nontraditional engineering undergraduates through narrative inquiry, was guided by the following research question: How do nontraditional undergraduates within engineering education experience bias, related to themselves as financially self-supporting, adult learners, and with what outcome $(s)$ ?

\section{Literature Review}

The literature review consists of five sections. The first section focuses on how the nontraditional student construct has been defined and operationalized within the research literature. The second section reviews research related to nontraditional student outcomes in higher education; the third section examines factors found to inhibit nontraditional student participation and success. The fourth section evaluates research related to perceptions of nontraditional and adult undergraduates. The review concludes with a discussion of this study's contribution to the existing literature.

\section{Who are Nontraditional Undergraduates?}

For nearly five decades, the term nontraditional (see, e.g., Cross, 1980, 1981) has been used to describe postsecondary students whose set of experiences differ from those historically considered as typical or normative (i.e., "traditional") among undergraduates enrolling at four-year colleges and universities. Choy (2002, p. 1) defined the traditional undergraduate as “... one who earns a high school diploma, enrolls full time immediately after finishing high school, depends on parents for financial support, and either does not work during the school year or works part time." In contrast, it has proven difficult to define who nontraditional undergraduates are as directly and succinctly. Scholars (e.g., Bean \& Metzner, 1985; Horn, 1996, p. 3; Jones \& Watson, 1990) have identified several characteristics as critical facets of nontraditional undergraduate experience, including: personal factors such as age, race, ethnicity, and gender; situational factors such as residence (i.e., commuter students) and enrollment in non-degree (i.e., certificate) programs; socio-economic factors such as socio-economic status (SES), employment level, and financial independence; and academic factors such as first generation college status and enrollment patterns (e.g., full-time or part-time enrollment),

Amid critique of an ongoing monolithic treatment of nontraditional students within the research literature (Pascarella \& Terenzini, 1998; Richardson \& King, 1998), Horn (1996) proposed a continuum approach to identify nontraditional students in a way that captures as well as categorizes the complexities inherent to their experiences. The model locates undergraduates along a continuum of experience; demarcations along the continuum are defined as the number of statistical risk factors that each student possesses. These risk factors, or nontraditional student "characteristics" (Horn, 1996, p. i), reflect the "choices and behavior that may increase students' risk of attrition and as such, are amenable to change or intervention at various stages in a students' school life" (Horn, 1996, p. 3). They include: (a) delaying college enrollment by one year or more; (b) attending college part-time; (c) supporting themselves financially while enrolled; (d) working full-time while enrolled; (e) having dependents other than a spouse; (f) being single parents; and (g) having earned a GED or other equivalency certificate in place of a high school diploma (Horn, 1996, p. i). While Horn (1996) classifies undergraduates who display at least one characteristic as generally nontraditional, she categorizes undergraduates as minimally (possessing one characteristic), moderately (possessing two or three characteristics), or highly nontraditional (possessing four or more characteristics). Doing so accounts for an increasing risk of attrition among students who possess more than one to several characteristics (e.g., see Berkner, Cuccaro-Alamin, \& McCormick, 1996; Berkner, He, \& Catadli, 2002).

This study adopts Horn's (1996) model to guide purposeful sampling. Because sufficient but not extreme intensity (Patton, 2002) of experience is important to an examination of nontraditional student experience in engineering, volunteers who self-reported having three to six nontraditional student characteristics were purposefully selected for this study. In doing so, participants could be categorized as solidly within, but not at the extremes of, the moderately and highly nontraditional undergraduate categories proposed by Horn (1996) (see also the participant selection section). 


\section{Nontraditional Undergraduate Outcomes}

Researchers in the United States report that nontraditional undergraduates are a growing population who currently outnumber those who enter post-secondary institutions possessing traditional backgrounds. Several studies indicate that more than $70 \%$ of U.S. undergraduates (i.e., aggregated across community and 2-year and 4-year colleges and 4-year universities) possess at least one nontraditional characteristic and can be categorized as nontraditional (Choy, 2002; Horn, 1996; Radford, Cominole, \& Skomsvold, 2015). Choy (2002) also reported that the number of U.S. undergraduates who are highly nontraditional, when aggregated across all postsecondary institutions (i.e., 2-year and 4-year institutions) is equivalent to the number of traditional U.S. undergraduates. However, traditional undergraduates continue to predominate at 4-year institutions where most professional STEM degrees (e.g., engineering degrees) are awarded (Choy, 2002; Horn, 1996).

Despite increasing numbers of nontraditional students enrolling in higher education, traditional undergraduates continue to achieve higher outcomes on average. As a group, nontraditional undergraduates are twice as likely as traditional students to leave college during their first year and remain less likely than traditional students to earn undergraduate (i.e., associate's or bachelor's) degrees (Choy, 2002; Horn, 1996; NCES, 2002). Choy (2002, pp. 16-17), for example, found that the first-year attrition rate for U.S. nontraditional students pursuing bachelor's degrees in 1989-1990 was 27\%, compared to $14 \%$ for traditional students. During the same period, the first-year attrition rate for nontraditional students pursuing associate's degrees was $46 \%$, compared to $23 \%$ for traditional students (Choy, 2002, pp. 16-17). Others reported that the five-year degree completion rate for nontraditional undergraduates enrolling with the goal of earning a bachelor's degree (37\%) lags well behind that of traditional students (54\%) (NCES, 2002, p. 34). Moreover, Horn (1996) found that attrition rates increase with nontraditional student status; $42 \%$ of minimally nontraditional students earned a bachelor's degree in five years, compared to $17 \%$ of moderately nontraditional students and $11 \%$ of highly nontraditional students (p. ii).

\section{Nontraditional Undergraduate Outcomes in STEM}

STEM undergraduates are often considered separately from those who matriculate in non-STEM majors due to the marked contextual variations between their experiences. Drawing from several nationally representative, longitudinal datasets of postsecondary undergraduates in the United States (i.e., Beginning Postsecondary Students Longitudinal Study (BPS: 96/01), National Postsecondary Student Aid Study (NPSAS:04), and the Education Longitudinal Study of 2002/06 (ELS:02/06)), Chen and Weko (2009) reported that STEM undergraduates who were over age 20 or financially self-supporting were statistically less likely than younger and financially dependent undergraduates to enroll, persist, or complete bachelor's degrees. While younger and financially dependent students were likely to leave STEM programs by changing to a non-STEM major, older and financially self-supporting students tended to leave STEM programs by exiting postsecondary education altogether (Chen \& Weko, 2009). Although research that examines nontraditional student achievement and retention within engineering is nascent, it is on the rise. A substantial portion of current work focuses on understanding engineering transfer student pathways (e.g., Mobley \& Brawner, 2013; Mobley, Shealy, \& Brawner, 2012, 2013; Ogilvie, 2014; Ogilvie et al., 2015, 2016; Shealy, Brawner, Mobley, \& Layton, 2013; Sullivan et al., 2012). Ogilvie (2014), for example, points to a gap in the literature related to transfer student pathways in engineering and calls for more research to better understand engineering transfer student success.

Others (McNeill, Long, \& Ohland, 2014; McNeill \& Ohland, 2015, 2016) examined data from the MultipleInstitution Database for Investigating Engineering Longitudinal Development (MIDFIELD). MIDFIELD contains longitudinal, engineering undergraduate record level data gathered within 11 large and public research universities in the United States. McNeill and Ohland (2015) reported that nontraditional engineering undergraduates (i.e., those age 24 or older at first matriculation) were more likely than traditional (i.e., younger) engineering students to graduate with engineering degrees in six years; they also found nontraditional (i.e., older) engineering students were to be more likely to leave the institution without a degree. These seemingly contradictory findings suggest that nontraditional (i.e., older) engineering undergraduates may possess a high level of commitment to earning an engineering degree and/or entering the engineering profession. Yet, if they cannot complete the engineering degree, they may be unaware of opportunities within majors outside of engineering, uninterested in other majors, or lack adequate resources to change majors and continue (McNeill \& Ohland, 2015, p. 5). Others examining MIDFIELD data (McNeill et al., 2014; McNeill \& Ohland, 2016) reported that the academic outcomes of nontraditional students (i.e., those age 24 or older at first matriculation), measured as mean engineering grade point average (GPA), mean final cumulative GPA, and six-year engineering graduation rate, were on par with or better than those of their traditional counterparts. 
Because MIDFIELD contains few categories that reflect nontraditional student characteristics (see McNeill \& Ohland, 2015; McNeill \& Ohland, 2016, for discussions of current MIDFIELD limitations and plans for its upcoming expansion), researchers who explore nontraditional student outcomes in engineering using MIDFIELD data often define nontraditional students through age and/or enrollment status only. McNeill and Ohland (2016), who disaggregated MIDFIELD data related to student transfer status as well as age and enrollment status, reported that transfer status had a larger effect on student outcomes than age and/or enrollment status. Since transfer status is often considered to be a proxy for financial self-support, full-time employment, and/or having dependents, this finding suggests that consideration of additional nontraditional student factors is important for understanding the nontraditional student experience in engineering.

\section{Barriers Faced by Nontraditional Undergraduates}

Researchers point to several barriers that inhibit full participation of nontraditional students in postsecondary education; time spent fulfilling other responsibilities (e.g., family obligations and work requirements) is perhaps the factor that is most often highlighted for impacting nontraditional student achievement and retention (Gonclaves \& Trunk, 2014; Kenner \& Weinerman, 2011; National Survey of Student Engagement Annual Report, 2006; Wyatt, 2011). Other factors include administrative inflexibility toward nontraditional student needs and scheduling constraints (Benshoff \& Lewis, 1992; Gonclaves \& Trunk, 2014; Zacharakis, Steichen, Diaz de Sabates, \& Glass, 2011), inattention and uncaring attitudes of academic advisors and staff members towards nontraditional students (Gonclaves \& Trunk, 2014; Wyatt, 2011), a lack of nontraditional student organizations and peer networking opportunities (Benshoff \& Lewis, 1992; Gonclaves \& Trunk, 2014), and pervasive feelings of isolation and not fitting in among student peers (Gonclaves \& Trunk, 2014). Scott and Lewis (2012) observed that older (age 48+) students held differing "perceptions of acceptance" among faculty and younger student peers (p. 1). While the nontraditional students felt that interactions with their instructors were positive both in and out of the classroom, they considered their interactions with younger student peers to be "not as communicative," "distant," "minimal," and even "hostile" (Scott \& Lewis, 2012, p. 6). Hostile interactions were attributed to several factors including: (a) the substantial interaction among nontraditional students and the instructor; (b) a majority traditional student population in the class; (c) ethnic diversity within the class; and (d) minimal support for student peer interaction provided within the classroom curricular framework (Scott \& Lewis, 2012, p. 6).

Other findings report that nontraditional students tend to ask more questions in class, prepare more drafts of writing assignments, and come to class unprepared less frequently than traditional students (National Survey of Student Engagement, 2006). Others scholars (Bye, Pushkar, \& Conway, 2007; Zacharakis et al., 2011) report that interactions with caring faculty, who treat each student as "an active partner in a shared learning experience" (Bye et al., 2007, p. 155), have positive effects on nontraditional students' motivations and interest. These results point to the profound impact that interactive classroom experiences and supportive studentinstructor relationships may have on nontraditional student success.

\section{Perceptions of Nontraditional Undergraduates}

In an era characterized by substantial growth in the number of nontraditional students pursuing postsecondary education, several scholars (Donaldson \& Townsend, 2007; Pascarella \& Terenzini, 1998) critique a lack of research attention paid to "adults students" presence and their impact upon nonprofit higher education" (Donaldson \& Townsend, 2007, p. 28). Quinnan (1997) suggested that there has been little advancement, in terms of research questions, methodologies, and protocols, in adult undergraduate research since its inception. Donaldson and Townsend (2007) contend that the discourse related to adults students within the literature is inconsistent and "... frequently treats them as different, but not positively different, from traditional students, or else it accepts them but does not embrace them" (p. 45), pointing to the need for further research concerning nontraditional student experience in higher education.

Others (Haselgrove, 1994; Kasworm, 1990; Marshall \& Nicolson, 1991; Richardson \& King, 1998) agree that "discussions about the role of adult students in higher education tend to stress their supposed needs rather than the potential benefits they can bring" (Richardson \& King, 1998, p. 66) and suggest that it is common for adults to be considered, a priori, deficient in several areas: study skills, time management skills, intellectual ability, and potential for academic performance (Richardson \& King, 1998, p. 70). Kasworm (1990) labels these disparaging views of the capabilities of adult learners as “. $\ldots$ an insidious negative mythology regarding adults students' impact on the campus culture" that is akin to perceiving adult students "... as retreads in a form of 
salvage operation" (p. 156). Kasworm (1990) suggests that faculty and administrators often act out of the "fear that the inclusion of adult students will lower standards and create a new set of problems demanding special resources from the institution" (p. 156). Finally, Kasworm (1990) warns that those without prior experience working with adult students are most likely to operate from these negative biases (p.157).

Perceptions of Nontraditional Undergraduates in STEM

There is evidence to suggest that nontraditional students in STEM may encounter pronounced bias due to cultural norms existing within STEM disciplines. Conefrey (2001), for example, described widely held cultural beliefs that work to maintain an insider/outsider binary within science-related fields. Of the twelve "myths" she exposed, the following portend negative outcomes for nontraditional students in STEM: (a) science is genderneutral and value-free, (b) science is a meritocracy, (c) curricular and pedagogical change in science is unnecessary, (d) challenge and competition is necessary for science, (e) failure is the individual's fault, and (f) each scientist's classroom is his castle (Conefrey, 2001, pp. 174-178, 182). Describing so-called "second tier students" in science, Tobias (as cited in Foor, Walden, \& Trytten, 2007) writes,

Unless they are unusually self-motivated, extraordinarily self-confident, virtually teacher- and curriculum-proof, indifferent to material outcomes, single-minded and single-track, in short unless they are younger versions of the science community itself, many otherwise intelligent, curious, and ambitious young people have every reason to conclude that there is no place for them in science [47]. (p. 112)

Foor et al. (2007) highlight the lack of opportunities within engineering education for students whose life experiences differ from the "mythical norm of engineering ... that of the high-achieving, elite, white male" ( $p$. 103). They recommend that engineering faculty (a) be wary of "us' and 'them' classroom dynamics" that form due to differences in capital possessed by students of varying backgrounds, (b) recognize that students who earn average grades often become skillful engineers, and (c) be more accessible for working students who are unable to attend office hours (p. 113).

\section{Significance of this Study to the Literature}

Within the United States, nontraditional students are a promising source of future engineers. While data indicate that this population is increasing across postsecondary institutions generally, nontraditional student achievement, particularly in STEM, continues to lag behind that of traditional students. Because current work focuses on the examination of nontraditional enrollment and retention trends using quantitative research approaches, nontraditional student experience in engineering remains largely unexplored. This narrative inquiry project adds to the literature by employing counter story to provide a deeper understanding of how nontraditional engineering students strive for and achieve success, despite facing social and institutional bias related to their ways their socio-economic backgrounds and life situations differ from engineering cultural norms.

\section{Theoretical Framework}

This study is framed theoretically by foundational work related to deficit thinking (Irizarry, 2009; Valencia, 1997) and Feminist Theory counter story (Nelson, 1995).

\section{Deficit Thinking}

Deficit thinking occurs when negative perceptions of the "ability, aspirations, and work ethic of systematically marginalized peoples," particularly those who are socio-economically disadvantaged and/or belong to ethnic/racial minorities, are used to account for their disproportionately low academic achievement (Irizarry, 2009). Within K-12 education, deficit thinking is harshly criticized for its effect of relieving schools of their "responsibilities to educate all students" by assigning root cause of failure to individual students and/or to their communities and families (Irizarry, 2009). Deficit thinking, therefore, is not only psychologically harmful to diverse students, but also works to limit their academic achievement indirectly through institutional policy and school curricula. 
Nelson (1995) tells us that persistent expression/embodiment of negative attitudes, stereotypes, and bias by those in authority can easily become "dominant stor[ies]" of a faceless "Other" (p. 34). If dominant stories are (re)-told sufficiently and well, their (re)-telling can ingrain conscious and subconscious thought patterns among education stakeholders: administrators, faculty, and even students themselves. In this way deficit thinking-and the dominant stories it engenders - is able to invalidate diverse students' individual academic abilities and commitments to learning and to negate the relevance and value of the nonacademic knowledge and skills they bring to their education (Haselgrove, 1994).

\section{Counter Storying}

Nelson (1995) reminds us "anyone can tell a story" (p. 34). Polkinghorne (1988) explains how the temporal, chronological organization of narrative and storytelling is necessary for understanding human activity and recognizing how our actions affect our goals (p. 18). In suggesting that "the stories we tell ourselves and the stories others tell about us, [are] ... in essence our reality ... who we are and who we are becoming" (Schaefer, Lessard, \& Lewis, 2017, Theoretical Frame section, para. 1), Schaefer et al. (2017) propose a unique and powerful link between narrative story-telling, experience, and being.

Nelson (1995) continues by saying that "just as anyone can tell a story," "anyone can tell a counter story" (p. 34). While counter stories are written and told just as other stories are, they have particular characteristics that allow them to "counter" or dispute specific elements of dominant narratives: Counter stories are authored from the standpoint of the marginalized "Other," are "capable of attending to difference," and are " told for the specific purpose of undermining a dominant story" (Nelson, 1995, p. 34). The true purpose of counter stories, then, is not wholly to undo the dominant story, but rather to "set into equilibrium certain details or moral interpretations the dominant story ignores or underplays, thus allowing ... for dissent from the interpretation and conclusions the dominant story invites" (Nelson, 1995, p. 34). Like all stories, counter stories offer rallying points for group action and may lead to lasting impact. Within educational settings, counter stories allow marginalized students to "... enter the [dominant] story sideways, ... correcting for the biases and distortions of the dominant interpreters" and opening up "access" to the valuable "goods" of school communities to all students (Nelson, 1995, p. 36).

\section{Methodology}

This study used the qualitative methodology known as narrative inquiry (Clandinin, 2013; Clandinin \& Connelly, 2000) to examine and map the lived stories of undergraduates who pursued engineering degrees as nontraditional students. Dewey (1938, p. 23) asserts that the "connection ... between the achievements of the past and the issues of the present" exists "within experience." Narrative inquiry, which "derives from the Deweyan view of experience (particularly situation, continuity, and interaction)," is a relational, transactional research methodology framed by 3-dimensional narrative-inquiry space consisting of the personal/social (interaction), time (continuity), and place (situation) (Clandinin \& Connelly, 2000, pp. 49-50). While narrative inquiry involves storytelling, it is more; "Narrative inquiry is a way of understanding experience. It is a collaboration between researcher and participants, over time, in a place or series of places, and in social interaction with milieus" (Clandinin \& Connelly, 2000, p. 20). Thus, narrative inquiry is often described as “... people in relation studying people in relation" (Clandinin, 2013, p. 23). The strength of narrative inquiry lies in its ability to develop detailed understanding of human action through in-depth and personal examination of experience.

\section{Method \\ Participants}

Volunteers were recruited via email from a list of students who had graduated from the transfer program or completed (at a minimum) the Engineering Statics course taught within the program. Because Engineering Statics is (commonly) the first engineering course that engineering students encounter, Statics completion was considered a reasonable requirement for participation because it ensured that participants had experienced actual engineering instruction. Volunteers who responded to the initial email were provided with a link to an online survey used to screen for nontraditional undergraduate characteristics (Horn, 1996). To insure sufficient but not 
extreme intensity (Patton, 2002) of nontraditional student experience, only those volunteers who responded as having three to six characteristics were accepted as participants.

All participants were white and one was female. Programmatic data show that the group from which participants were recruited was characterized as less than $4 \%$ female and fewer than $22 \%$ nonwhite. Among those students who had graduated from the program by the time recruitment began, there were no females and fewer than $13 \%$ were nonwhite. These data suggest that participants represented the larger student body on gender and racial characteristics. The nontraditional characteristics most frequently shared among the participants included having breaks of one year or more between high school and college, working full-time and/or enrolling part-time at some point during the program, being financially responsible for themselves and any dependents, and having dependents other than a spouse. Only one participant had earned a GED in place of a high school diploma and one other was a single parent.

\section{Data Collection}

As the researcher, I met individually with each participant, either in person or virtually, twice over the initial 7month period. During this period, I conducted formal data collection and analysis by jointly constructing longitudinal narratives with each participant. For most participants, these research conversations strengthened existing relationships that had naturally developed during the transfer program as I taught and mentored students there. Our meeting arrangements were mutually agreed upon and I led our conversations using an in-depth, semi-structured approach (Hesse-Biber, 2014). Conversations were digitally recorded (audio only), transcribed, and reviewed for accuracy before being used in analysis.

During each initial meeting, I posed discussion prompts modeled after the interview protocol used by Pawley (2013) to conduct narrative research with underrepresented minorities in engineering education. The prompts worked to fulfill the project goal of eliciting participant reflection and storytelling and included questions such as: (a) Where are you in your life now? (b) How would you describe your background? (c) What were your goals? (d) What obstacles did you face? and (e) What successes did you achieve? At the end of each initial meeting, I asked participants to draw/write personal journey maps (Nyquist et al., 1999) to prompt deeper reflection and elicit further detail about their personal experiences during our second meeting. Shortly after each meeting (within the next day), I completed a post-interview reflective memo, based on Miles and Huberman's (1994) contact summary form, as proposed by (Pawley, 2013) to capture my initial impressions of the stories shared, summarize the information gathered, and reflect on the information that would be useful to get during follow on conversations.

After the conclusion of each initial meeting, I developed unique questions to pose to each participant during subsequent meetings. These questions were based upon analysis and chronological ordering of participants' personal stories shared during the initial meeting. During subsequent meetings, each participant and I jointly reviewed the written transcript from the first conversation, the participant's journey map, and the initial analysis of their stories. After the completion of all formal meetings, participants were provided with a $\$ 30$ gift card to either the university bookstore or big box store of their choosing.

Once these formal research conversations were complete, I began the process of co-constructing a longitudinal, experiential narrative (interim research text) with each participant. During this period, I shared electronic versions of narratives with each participant. I solicited written feedback via email periodically until each narrative converged to joint agreement. As I worked to produce final research texts (i.e. journal articles) from interim research texts, I was in contact participants to request feedback on final research text drafts and updates, if any, on their experiences since our earlier conversations.

The field texts (data) for this study include screening survey results, transcribed conversations, participant journey maps, researcher written reflections, written participant feedback on drafts of the longitudinal narratives (interim research texts), and written participant feedback on final research texts and updates about their experiences since our initial meetings. This study was conducted with approval from our university's institutional review board; all participants are required to give informed written consent prior to data collection. 


\section{Data Analysis}

Narrative analysis (Polkinghorne, 1995) was conducted by co-developing longitudinal narrative accounts, similar to life stories (Atkinson, 2007), with each participant to communicate their experiences of engineering education. Polkinghorne (1995) explains that, in performing narrative analysis, "the researcher's task is to configure the data elements into a story that unites and gives meaning to the data as contributors to a goal or purpose" (p. 15). These narrative accounts served as interim research texts; elements from the collected narrative accounts are also being developed into final research texts (Clandinin, 2013). The work of constructing and negotiating narrative accounts with participants helped to ensure that analysis and interpretation was accomplished collaboratively while honoring the ethical considerations and relational nature of narrative inquiry methodology. Trustworthiness of the accounts was supported by considering each participant (i.e., "storyteller") as "... the expert and the authority on his or her own life, thus having final say in what gets told" (Atkinson, 2007, p. 239). Participants chose how to represent themselves within their stories, using either first name pseudonyms or their actual first names.

\section{Findings}

Findings from this study are presented as nontraditional undergraduate narratives of encountering, embodying, and countering deficit thinking in engineering education. Due to the length of the detailed individual narratives, this work was limited in sharing from only two of the 14 participant stories developed during the project: Clair, a 22-year old, moderately nontraditional (three characteristics) white male; and Joe, a 29-year, old highly nontraditional (five characteristics) white male. Because deficit thinking emerged across the range of participant stories, the choice of whose stories to present involved several considerations. First, as the data generally broke down as younger, moderately nontraditional students and older, highly traditionally students, one story from each category (i.e., one younger/moderately nontraditional story and one older/highly nontraditional story) was selected for presentation. Second, to present findings centered within potential extremes of experience and more apt to resonate with most readers, participants whose time spent in the transfer program (i.e., time to associate's degree completion) was centered within, and not at the limits of, the range of associate's degree completion times represented within each category were selected for presentation. One unintentional benefit of presenting the stories of Clair and Joe, both white males and participating members of the dominant local culture, was to highlight how being nontraditional, in and of itself, may be enough to catalyze deficit thinking within engineering education.

\section{Clair}

Now a mechanical engineer/structural analyst for a large aerospace engineering firm, Clair thought back to the time when he and his wife, as newlyweds, enrolled as undergraduates at the regional campus, he in the engineering transfer program and she in elementary education. Shaking his head with a half-grin, half-grimace, he remarked how "Those were the longest days of my life. We both look back and think that was a miserable point in our lives."

The irony of "those" days is not lost on Clair. Finally getting about the business of becoming an engineer-the thing he had wanted to do since he was a young boy building his inventions in his parents' backyard-Clair had been "scared to death" for the entire first year he was in the transfer program. He explained how he enrolled in the program "not knowing how I was going to accomplish my goal but knowing I had to take a step forward."

Clair's goal, ever since he could remember, was one of becoming an engineer. He talked fondly about his childhood - especially the hours and hours he spent building and creating in the wide-open space behind his childhood home, nestled in a corner of the Texas ranch where his family lived and his dad worked as an animal physiologist. During these hours in the backyard, Clair — in effect—was figuring out who he wanted to become. Clair said:

Even when I was really, really young, I'd be out back building my ideas and coming up with how to do things differently. And I remember that I asked my mom, "Who does this type of stuff in the real world? ... I didn't have the slightest clue. ... I asked my mom and she said, "You know, engineers do that type of thing." And so after that I said, "I want to be an engineer." And I told everybody, for the rest of my life, that I wanted to be an engineer. 
Today, Clair laughingly admits that he isn't sure if he stuck with his engineering story all those years "... out of stubbornness or because that's what I had told everybody."

\section{Embodying Deficit Thinking}

Clair describes his high school self as a "terrible student." In fact, he was the kind of student who would "... sit down one night and figure it out —right before the test—and then ace the test" without really trying. Clair "didn't try" in his most of his classes because none of his high school subjects interested him, except for the automotive class. The highlight of his high school days, in fact, came at a national automotive competition as he was awarded a scholarship to a 2-year Texas college to earn an associate's degree in automotive technologies. Clair figured that, once he earned his associate's degree and gained marketable skills for a "decent paying job," he would go to a 4-year university- "somewhere"- to study engineering. Eventually, he hoped to become an automotive engineer and maybe even start his own company to design and fabricate custom parts. Since Clair's parents had instilled in him an admirable and inexorable resistance to accepting loans of any kind-without having means to support him financially - that initial 2-year scholarship was a critical part of Clair's plan.

But Clair never used that scholarship. Much happened in the four-plus years that passed between Clair's high school graduation and entry into college. After graduating, Clair temporarily deferred his scholarship, worked any part-time job he could get, and waited for a mission call from his church. The mission call came 14 months later and Clair spent the next two years abroad in St. Petersburg, Russia. Clair remembered how, "The whole time I was on my mission I thought, 'I'm going to use that scholarship down in Texas.' The whole time, that is, until my mom got cancer again." Upon returning stateside, Clair made a difficult decision to give up his scholarship and spend time, whatever it took, helping her get well.

Thankfully, his mother fully recovered from her second breast cancer diagnosis. During the time he spent at home, Clair had the good fortune of finding a job he "loved, "working with his hands" while restoring old houses, as well as meeting, becoming engaged to, and marrying his wife. Soon after the wedding, the newlywed pair agreed that it was finally time for both of them go to college. So Clair, at 22 years old, and his wife packed up and moved to a different city in another state so that Clair could enroll in the engineering transfer program. He chose the program because of the regional reputation of the university in engineering, as well as the fact that the evening programming would allow both he and his wife to work while attending college.

Clair described how they walked into the regional campus advising office together to enroll, just after arriving in town, having "no idea what they were doing." Clair explained,

At the time I started, it was four and a half years I hadn't been in school—I hadn't done math in four and a half years! I'm embarrassed to say this - I couldn't test out of trigonometry because I couldn't remember it. All these kids going into the engineering program skipped out of calculus and I was starting in Algebra. I was scared because I wasn't a very good student in high school. I just didn't think I was smart enough to do it.

I met Clair at about this time. He was, in fact, the first student I met in my new position as an engineering instructor in the transfer program. I remember Clair knocking on my office door to ask for help with some math problems he was studying in advance of taking the placement exam. He was bright and energetic, but seemed a bit nervous and apologetic. I remember being inwardly surprised he was studying algebra, and not calculus, problems.

While Clair considered both his lack of effort in high school and his break between high school and college as major obstacles to becoming an engineer, it was also clear that he doubted his own personal abilities and intelligence, particularly with respect to his skills in math. He explained how engineering was somehow different than other subjects and, "even though I studied every day on my mission because I had to learn Russian, it didn't prepare me for studying engineering." As Clair wondered whether he was "smart enough" to do engineering, I imagined the courage he summoned walking into that advising office the day he came to town.

\section{Encountering Deficit Thinking}

Despite the personal stories of deficit that he told about himself early on, Clair began to craft a new story for himself as he worked his way through the transfer program. He and his wife each found part-time work situated 
at the regional campus. Flexible work schedules enabled them to take day or evening classes as needed. By reducing their schoolwork commute time down to zero, their jobs enabled them to spend maximum time and effort on their studies.

As he began taking classes, Clair was somewhat surprised that "all of my classes interested me except for, maybe, psychology. I just needed some interest and I started doing really well." Clair received all A's that first semester. "Oh, I can do this," Clair began to tell himself. "I can-if I just sit down and work hard, I can get good grades." Clair talked about how:

One of my earliest goals was to get good enough grades. Once I realized I could get good grades, then my goal became to get really good grades so that I could pay for school [through scholarships], because I had no other way [besides working] to pay for school.

Clair became self-motivated - just the way he remembered being in his high school automotive class. He started asking lots of questions in class - even, one day, to the point of annoying his calculus instructor. Clair told me: "I understood ninety percent of everything. But I wanted the last ten percent and I was working my butt off to get it." He started to experience a synergy by being — studying and working — on campus. Faculty and staff members "saw me working hard to do this and they appreciated it. Their appreciation motivated me to work even more."

Clair experienced considerable success in the transfer program. Just shy of his 25th birthday, Clair graduated as Valedictorian of his transfer program graduating class. Now, he had a new story to tell:

When I left the ... program, I felt like it was a success because when I was done I felt like if somebody asked me how to do something, I could do it. I remember loving thermodynamics and thinking, "I could dominate in the thermodynamics world. This is awesome." And granted, that was a pretty basic class. As you get farther into it, you learn that there is way more to this. But that was one thing that I remember always feeling proud of - that I actually knew what I was doing.

Clair's academic success earned him two scholarships which together completely funded his tuition for his final two years of engineering study. Riding the high of his successes, Clair took newfound confidence with him to the main campus mechanical engineering program.

Somehow, though, things were different for Clair after he started classes on main campus. He felt that "atmosphere changed"-it became "... as if nobody cares about you [and] you're just a number." One recollection of a classroom experience really bothered him. One day, an engineering instructor told the class that this was their "weeding out period, and if you have anything else you want to do right now, put it on the back burner." Clair remembered thinking how "rude" the statement and how uncaring that instructor were.

Clair's feelings of isolation went deeper still. Clair talked about how he:

... told some of the [engineering] instructors that I came from the [transfer] program and they kind of got this look on their face-like depressed looking. And they said something like, "Oh, okay, well, yeah, good luck over here."

These unsettling experiences with engineering faculty began to work—negatively—on Clair's motivation. After those experiences, he stopped trying so hard. Clair said:

My motivation decreased in a major way.... And by that, I mean the motivation to excel. The motivation to become an engineer was still there. The motivation to be at the top of my class left. I didn't try extra hard. I just did what I needed to and I didn't go after that last ten percent like I did in [the transfer program]. I settled for understanding enough to get a good grade.... And then I moved on.

His classroom behavior changed, too. Clair found himself too embarrassed to ask questions in the large engineering classes that were common on main campus. Sitting in class with a question on his mind, Clair often thought to himself: "I'm sure so many other kids understand it. I'm just going to go home and try to figure it out." In this new environment, Clair's story of becoming changed, as he found that he "had to figure out how to learn without asking questions in class." 


\section{Countering Deficit Thinking}

For Clair, one bright spot during the professional program came during his senior capstone design course. Clair became the leader of a team of mechanical engineering seniors who, as part of the Crossing the Gap competition for university engineering students run by the Air Force Research Laboratory (AFRL), was tasked with designing and building a collapsible structure weighing approximately twenty pounds, measuring under four and one-half cubic feet when collapsed, that was quickly deployable and could hold 350 pounds. The structure was intended for use by "U.S. Special Forces agents [who] need to scale a wall, traverse a canal, or cross between rooftops" (Hwang, December, 2013).

For Clair, this senior design project was the "ideal" engineering learning experience because he was given "freedom to create something that came from an idea that I had." He said:

When they came to us ... and said, "Hey, here's a list of requirements figure out how to accomplish it," that was really fun to me-I enjoyed that. I like the fact that somebody just said, "Here are the requirements. Figure out how to accomplish it kind of creatively and inventively so."

The design and prototype developed by Clair's team turned out to be wildly successful, winning the AFRL competition and being featured in the December 2013 issue of Popular Science magazine (Hwang, December, 2013). Now, Clair told a new story of passion and confidence as he discussed how his team worked together on the project:

Even though senior design was super difficult and I felt like beating my head against the wall a lot of times, all my initial ideas were eventually polished into something that was better than I had come up with because of the group discussions. No one part of that design was any one person's idea exclusively. The concept might have been one person's idea, but it all got improved because of everybody's work.

Amid disappointing and demotivating interactions with engineering faculty during the professional program, the senior design AFRL competition provided Clair a rewarding, memorable experience in which he took an opportunity to lead his peers in an area in which he naturally excelled (engineering design). While Clair's senior design experience did little to improve or reshape his relationships with the engineering faculty, it did provide him an alternative environment within which to find renewed motivation to excel.

Clair completed his bachelor's degree in the spring of 2013, four and one-half years after he began. He quickly landed an aerospace engineering job that was "better than most people dream of" and put him right where he wanted to be- except, perhaps, for the industry. Still, Clair keeps his entrepreneurial dream alive by working on his inventions nearly every day.

Thinking back to our last conversation, I remember that Clair told me how he was "a little bit bitter" about the way he was treated in the professional engineering program. I admit that I was startled when he confessed he hadn't attended his bachelor's degree graduation ceremony. In response to my overt reaction, Clair described how he holds no lasting sense of enthusiasm or loyalty for his alma mater, saying,

I don't feel like they did me any favors ... I mean, you transfer [to the four-year engineering program] and they're anticipating you to live, breathe, and do school. I mean, that is what they expect of you. And if you're nontraditional, you have to figure it out, you know? And maybe if I would have just been like I'll go into debt, whatever, and I'm just kind of out of [high] school ... that might have been different.

Frustrated with faculty's seeming distrust of his abilities and lack of accommodation for his needs as a nontraditional student, Clair could only imagine how his story of becoming an engineer would have been different had he been different, that is, had he been more like his traditional undergraduate peers. Alternatively, lingering in the aftermath of Clair's story, I am left wondering how Clair's experiences - as well as those of students like him - could be different if institutions themselves were asked to change. What could nontraditional student outcomes in engineering look like if faculty became better able recognize professional engineer potential among nontraditional undergraduates, and if engineering programs became better able to meet nontraditional undergraduate needs and constraints? 
Joe

Joe was 29 and married when he enrolled in the engineering transfer program in the fall of 2009. He and his wife welcomed their first child, a son, in 2010 when Joe was in his second year of the program. During these years, Joe supported himself and his family working as a full-time heating, ventilation, and air conditioning (HVAC) technician at a national aerospace engineering firm located roughly 30 miles - about a 45-minute drive-from his home. He had started there as a part-time worker in 2007, and within four short months had been hired full-time. Joe's decision to enroll in the transfer program and earn his engineering bachelor's degree while supporting his growing family came after spending over 10 years pursuing other serious endeavors after high school, including serving a two-year mission for his church in the eastern United States, working as a HVAC technician for a small local company, working as an independent mechanical contractor, and seriously considering training for a career as a commercial airline pilot, either by joining the U.S. Air Force or enrolling in private flight school.

\section{Encountering Deficit Thinking}

When Joe enrolled in the transfer program, it had been ten years since he had graduated high school. In the fall following his high school graduation, Joe had enrolled for a single semester in the university's engineering program to fill the time as he waited for his mission call. At that time, Joe didn't make much progress toward a degree but blamed his lackluster performance on just "not being ready for college" yet. While he considered himself to be a good student who knew how to study, Joe was certain that he had forgotten most of what he had ever learned about college-level mathematics by the time he enrolled in the transfer program.

To make up for what he felt was lacking in his preparation as he entered the transfer program, Joe and his wife decided that it would be best for Joe to restart his mathematics education at the very beginning with Basic Math. While this decision added a few years and several courses to his program of study, Joe never regretted this decision in terms of his academic preparation; Joe found his math courses to offer some of the biggest yet most rewarding challenges he faced in the program. Joe did, however, regret some of the personal interactions he experienced as he entered into engineering math courses. One experience in calculus particularly bothered him:

The first day of class the instructor told us, "All right, this is how many points you need to get a C minus. This is how many points you need to pass the class"- and that was it and then he moved on. I was like, "You're not going talk about what it takes to get a B or an A?" But that was the expectation-we were all just trying to pass and could not really do well in the course. It made the biggest difference when the teacher just expected you to fail. That's what I felt like in some of those classes.

After making a substantial commitment of additional time and money to help insure his mathematics preparedness and future success in engineering, Joe found it not only surprising and confusing, but also frustrating and demeaning, being met by engineering calculus instructors who assumed that he and his nontraditional classmates had little interest in or aptitude for learning calculus.

\section{Embodying Deficit Thinking}

By all accounts, Joe had been a solid performer throughout the transfer program. As his thermodynamics instructor, I had noticed his keen interest in the course material. Joe told me how thought it was "cool" that, after taking that course, he could "run calculations for HVAC systems as well as fix them." He was proud how his strong efforts in the transfer program enabled him to work closely with and for the facilities engineers at his place of employment, noting how the other technicians employed there could not do so. Joe talked about how "Taking thermodynamics has really helped me understand refrigeration at a level where I just get it and can readily explain things about it to other technicians and engineers. I couldn't do this before going back to school."

Sometime after Joe had completed the thermodynamics course, his manager surprised him with an offer to participate in an engineering internship at the company. After some serious deliberation, Joe accepted the offer, "even though I was very busy with school, because they said 'You'll be doing HVAC, you know, BTUs in and BTUs out, that kind of thing.", 
[But] it was all sorts of different things. I was like "Holy crap, I don't know how to do any of this stuff!" I was really nervous and felt very inadequate at first. I had to learn all of the other computer programs that ... the engineers deal with on a regular basis that I'd never used before.... That was the first month. I was like "Why am I doing this? I hate this." But later on, I kind of enjoyed it.

In the end, Joe was grateful for the experience; he decided that it was a clear sign that his management was on board with his educational pursuits and perhaps even was interested in the prospect of him moving into an engineering position at the company in the future.

Joe graduated from the transfer program in the spring of 2015 after completing the entire mathematics sequence - from basic mathematics through differential equations and linear algebra - as well as the first twoyears of engineering curriculum within six years. To Joe, graduation was an important personal milestone-not because of any financial benefit he hoped to receive from earning his associate's degree, but rather because graduation from the transfer program marked a midpoint in his studies:

[Graduation from the transfer program was] just over halfway for me because I had to retake all of those math courses. At the beginning, I looked at all those math classes and I was like, man, I'm never going to get through all this. I hated the beginning of every semester but I felt so good at the end of every semester, being that much closer. I had papers that list all the classes I had to take. When I ... cross[ed] off one ... it felt so good.

Joe transferred to the main university campus the next fall and began the rest of his engineering studies alongside more traditional student peers. At that point, he estimated that it would take him an additional 3-4 years to complete his bachelor's degree in mechanical engineering.

Early in the spring of 2016, I emailed Joe and asked him for his feedback on an interim research text I was preparing. Soon, we began talking about his current experiences on main campus. I knew from our previous conversations that he had been very concerned about the transfer-how it would all play out for him as he tried to juggle day-time classes and a full-time work schedule yet still give time and effort to his roles as husband and father. He had talked about the most difficult days in the transfer program "... where I didn't see my son at all," acknowledging how he and his wife were jointly committed to enduring these sorts of hardships "for the wellbeing of our family in the future." By the time he was ready to transfer to the main campus, Joe had grown very anxious about what this next phase would require of him and his family. When I asked him about his first semester on main campus, Joe told me this story:

This semester was really tough attempting to adjust to daytime class and nighttime work. My average workday was to leave for work at 1:00 pm and then return from work around 11:30 pm. On school days (MWF last semester) ... [my round-trip commute] was just over 2 hours and about 100 miles a day. Several times I planned on leaving work a little early to do homework right after work and then things would get really busy at work so I would "lose" time I had budgeted to complete some assignments.

Joe went on to compare his experiences within the transfer and main campus programs:

I think the biggest change for me ... [was] the additional commute [time] and [the] time required to get around campus. Another thing I felt was that, as class sizes grow [on the main campus], the instructors seem to have less time to answer questions and seem more concerned about getting through material. Getting help takes a lot more effort/time because it has to be face to face, so because of my schedule that was impractical.

Joe had taken a lighter than average load for engineering student, which consisted of "only three courses," that spring. He told me how he received a "B" in one course and barely passed the other two. I could tell, from his voice, how disappointed he was. He told me how he was also facing administrative repercussions - being barred from enrolling in some $3^{\text {rd }}$ year engineering courses-because his semester grade point was below a predetermined limit.

These repercussions would undoubtedly increase his time to degree. Obviously frustrated, Joe remarked, "I wish I would have been aware of some of these 'rules' at the beginning of the semester, because now it almost seems as though they are being made-up as I go.” Joe ended our conversation saying, 
I know I have put myself in this situation, as far as being a nontraditional student, but it sure is tough trying to hang in there with the traditional students. I keep feeling like the instructors/advisors must think I am a terrible student and that engineering may not necessarily be what I should be pursuing. If I had a chance to explain my situation, that school is really my third (major) priority, maybe they would better understand my seemingly lackadaisical effort, when sometimes that effort is truly all I can give.

Joe's very candid and personal response troubled me. In his words, I heard him questioning his own abilities and internalizing negative perceptions (e.g., "terrible student," "lackadaisical") about his student self. At this moment, his words stood in stark contrast to the expressions of pride and confidence he displayed as he graduated from the transfer program.

I thought about how, after just one semester taking classes in the engineering education environment of main campus, Joe had begun to question himself - whether he was good enough - and to perceive personal deficiencies within himself that came as a result his multiple identities as husband, father, employee, and student. Within his words, I heard an apology for being a nontraditional student, as if it was a mistake he had made or a misfortune he chose to endure. As the strength of his concerns led him to question his emerging identity as an engineer, I was left wondering how Joe would continue to fare as a minority within the dominant engineering culture.

\section{Countering Deficit Thinking}

I continued to converse with Joe, intermittently, via email. A little more than a year later, I emailed and asked him to review a draft research text I was preparing. Admittedly, I was nervous each time we communicated-I carried around with me lingering doubt that he would, one day, complete his degree. As I read Joe's message that day, I was struck hard by my own lack of faith and negative perceptions. "I have transferred to another university as a distance [engineering] student," Joe wrote. I sat there, staring at my computer, trying to imagine the circumstances that had driven Joe away from the physical university located approximately 30 miles from his home to a distance education program administered from approximately 1,800 miles away. Joe went on to write,

Two semesters at the ... [main] campus trying to attend the classes I needed whenever they were offered and having to adjust my work schedule accordingly was a little too painful.... I had looked into online [engineering bachelor's degree] programs in the past but could not find any that were accredited. However, after that first semester [on main campus] ... I started looking again and found two.

Joe found two accredited mechanical engineering programs online and was accepted as a transfer student at both of them. The transfer process - to another university system in another state-however, had been hard. "It literally took dozens of emails and phone calls over several weeks to sort through how all the credits ... would/could be applied." In the end, Joe chose the program that required the fewest on-campus visits. Joe told me:

When the time comes, I will have two classes that will require travel ... two or three times a semester. While that may sound ridiculous to most people, it is far more valuable to me to have a consistent schedule at work, than the cost of several trips ... to attend labs on the weekend. The main reason is I have a pretty good job now, and I just don't want to deal with the risks of having to change my work schedule each semester.

As I read and responded to Joe's message, I was overcome with relief at having heard Joe's new story of becoming. I am excited by Joe's possibilities within the profession as well as humbled by the drive, dedication, and sacrifice he has shown in discovering his own pathway to becoming an engineer. While Joe's narrative is not yet complete, he is once again optimistic and looking ahead to a future as an engineer.

\section{Discussion}

Clair and Joe's experiential narratives of encountering, embodying, and countering deficit thinking serve to demonstrate how students who are older, enrolled part-time, and/or working full-time working-even those with 
familial responsibilities - can be successful in undergraduate engineering education as well as in the profession of engineering. Their narratives serve to counter common deficit storylines that are (re)-told about nontraditional students in higher education. As depicted in the narratives, Clair and Joe faced substantial challenges as they negotiated a complex mix of personal, social, and institutional tensions while pursuing their engineering degrees. Yet, instead of merely identifying the barriers they faced, their stories describe and examine how each persevered and succeeded in engineering despite frequently bumping against deficit perspectives.

\section{Early Undergraduate Experiences in Mathematics}

Clair and Joe each experienced perceptions of personal deficiencies as incoming engineering students related to what they thought about their innate mathematical abilities and/or the current state of their mathematical skills. Clair admitted to being embarrassed about testing into algebra while his student peers, "these kids," were all starting out ahead of him in calculus. Being well behind his peers in math made Clair question his ability to become an engineer. These doubts were intensified because he had not gained sufficient confidence in math in high school. Joe, who had felt reasonably comfortable with math in high school, more readily accepted placement within Basic Math. Yet, despite rational acceptance of the need to hone his math skills, Joe was insulted by the words of his mathematics instructor, whom he perceived as jumping to the foregone conclusion that he and his peers did not have potential or desire to excel in math.

Because being calculus-ready is considered as the point of entry for engineering programs (National Academies of Sciences Engineering and Medicine, 2016), it is likely that many nontraditional engineering students face similar challenges related to mathematics instruction. Clair and Joe's stories reveal to us that nontraditional students may be inclined to engage in personal deficit thinking about their intellectual abilities to do engineering, based solely upon the current state of their knowledge and skills in mathematics. While choosing to (or being required to) take remedial mathematics courses is often a good course of action for nontraditional students academically speaking, it can exacerbate personal (e.g., financial, familial, employment) challenges faced by nontraditional students by necessarily increasing the time and expense associated with earning the degree. Joe, for example, took six years to complete the two-year transfer program. Joe's completion time was due in large part to his placement within Basic Math. One year of calculus is a standard prerequisite for even the most fundamental engineering courses. As Clair and Joe's stories show, remedial math placement may increase the social challenges that nontraditional students face if peers and/or instructors view the need for remedial mathematics training from deficit perspectives.

Thus, it appears that mathematics instruction plays a key role in the early experiences of nontraditional students in engineering. This seems true not only because mathematics courses are among the first that engineering undergraduates encounter, but also because nontraditional students may be particularly prone to personal deficit thinking about their abilities in mathematics. Moreover, early course failures in mathematics may be especially difficult for nontraditional students to rebound from, not only due to administrative rules concerning allowable course repeats and the inherent linearity of mathematics/engineering curricula, but also due to the need for students to overcome strong personal perceptions of math inadequacy reinforced through course failures. It is important for institutions desiring to promote nontraditional student participation and retention in engineering to make active, engaged, and supportive instruction, especially within mathematics, a top priority.

\section{Engineering Faculty Interaction and Instruction}

As Clair and Joe transferred to the 4-year university campus and entered the professional program, interaction with engineering faculty and engineering course instruction became obstacles to their success. Clair and Joe each cited the large class sizes and distant, seemingly uncaring faculty as factors that negatively affected their motivation for learning within that transitional year. After rising to a position of relative confidence and excitement about his ability to learn engineering within the transfer program, Clair very quickly began to feel isolated and ignored as he transferred to the professional program. These changes rapidly manifested in Clair's classroom actions; Clair went from being an avid classroom participant who worked to understand "that last ten percent" to being too embarrassed to ask questions, sure that "so many other kids" knew the answers to the questions he wanted to ask. Ultimately, Clair disengaged from classroom instruction to the point of just doing what he needed to and moving on.

Joe expressed how large class sizes within the professional program reduced the quality of the instruction, making it seem rushed and as if faculty were more interested in getting through the material than instructing. Joe 
found it nearly impossible, given his carefully choreographed work-school-commute schedule, to get out-ofclass help. The standard face-to-face office hours support was completely "impractical" for his needs and schedule; Joe could find no other available options. All in all, these stories help to highlight the importance of continuing faculty interaction and student-centered instructional approaches for nontraditional students throughout the engineering curriculum. It may prove particularly difficult for nontraditional studentsespecially those who transfer from a two-year program to a four-year program - to preserve their confidence and motivation. Moreover, it may be that the transfer (third) year is a particularly difficult juncture for nontraditional transfer students and that engineering curriculum stakeholder should focus resources to bolster instruction and student support during that year.

\section{Resilience and Goal Orientation}

While the narratives serve to reinforce the importance of instructor relationships and classroom instruction for nontraditional student success in engineering, they also demonstrate the personal resilience, perseverance, and ability of the nontraditional students to manage their actions based upon higher goals. Both students came into the transfer program with well-defined and interdependent goals. For Clair, these goals included the concurrent education of he and his spouse, his future career as an engineer-preferably within the discipline of automotive engineering - and his dream of, one day, becoming a self-employed entrepreneur. For Joe, goals for his education, for his current career as HVAC technician, and for his future career as an engineer-perhaps with his current employer-combined to create an overarching purpose of providing a stable future for his family. Unlike many traditional students “... who select engineering as a major without actually knowing what engineering is" (National Academies of Sciences Engineering and Medicine, 2016, p. 26), Clair and Joe enrolled with firm understandings of their educational/career/familial aspirations as well as personal convictions, grounded in experience, that they wanted to be engineers. Yet, because their educational goals were not singular and premier but interdependent, Clair and Joe were apt to shift their priorities in relationship to school, work, or family longitudinally over time. These shifts did not reflect a lack of time management or study skills as perhaps engineering faculty might perceive, but rather pointed to sophisticated long-range planning and a necessary reordering of responsibilities as they balanced their everyday lives in the hopes of reaching their long-term goals. In many ways, these stories reveal how nontraditional students often manage the same or similar personal, familial, and career-related activities as do educators, administrators, and staff and, perhaps, point to how nontraditional students could benefit from being treated by faculty and staff more as adult peers, from the sense of life experience, than as students.

\section{Limitations}

The findings presented in this study represent the experiences of only two nontraditional undergraduates. While their stories provide rich details of nontraditional student experience in engineering, they do not necessarily represent the experiences of all nontraditional students enrolled in the engineering transfer program or the broader group of nontraditional engineering undergraduates generally. Insights originating from the in-depth examination of only a few stories of becoming in engineering - as told by students who embody characteristics that serve as markers for deficiency and risk - are nonetheless valuable and worth (re)-telling. While the lack of cultural, ethnic, and gender diversity among the stories presented reflects the cultural influences of the geographical region, it also suggests that the stories presented represent but a glimpse of the broader landscape of nontraditional student experience. In addition, my own background-first as a nontraditional engineering graduate student 20 years earlier, as a practicing professional engineer, and as engineering instructor within the transfer program - undoubtedly influenced my desire to examine nontraditional student experience as well as my choice of theoretical frameworks to underpin this study. While the existing student-instructor relationships I shared with many participants made it easier for me to negotiate entry into their personal stories, they also required me to continuously manage my own preconceived interpretations of the stories they told. In retrospect, I believe it was perhaps my unique background that allowed me to first perceive and later acknowledge, after years of enculturation in engineering professional and academic culture, my own complicity in nontraditional student bias and to choose to examine this phenomenon from a collaborative, student-centered perspective.

\section{Conclusions and Scholarly Significance}

While Clair's narrative of living and learning as a nontraditional undergraduate in engineering may be considered complete, Joe's is still unfolding. As a former instructor in the transfer program, I was moved by the 
stories that we, as "people in relation studying people in relation" (Clandinin, 2013, p. 23), experienced and shared. The deficit perceptions described by Clair and Joe often echoed the isolation I experienced as I entered engineering graduate school upon my military discharge. At other times, their stories spotlighted the cultural perceptions and habits of mind to which, having spent many years immersed in engineering culture, I had become accustomed and even, at times, helped to perpetuate.

By accessing these unique views into the personal, social, and institutional tensions experienced by nontraditional transfer students, this narrative inquiry awakens new attention and sensitivity to the perceptions and bias that faculty, staff, and administrators may bring to their roles in engineering education. These in-depth insights, provided by nontraditional engineering students in the midst, present important implications for improving nontraditional student experience in undergraduate engineering education. Tentative conclusions from this study suggest that nontraditional students represent an important source of engineering human capital, with strong potential for completing undergraduate engineering degrees and becoming productive practicing engineers. Academic institutions should strive to reduce institutional tensions arising from rigid educational structures and policies, as well as social tensions stemming from poor instructor/advisor-student relationships and inadequate classroom engagement, since these may be among the most disruptive and difficult for nontraditional students to negotiate. To promote nontraditional student participation and success in engineering education, faculty, and administrators should consider the long-range goals of nontraditional students, as well as the unique knowledge and skills that they are apt to possess. Moreover, engineering curriculum stakeholders are encouraged to look for ways to make use of the range of experiences that nontraditional students bring to the classroom so that they might improve engineering education for all students.

\section{References}

Atkinson, R. (2007). The life story interview as bridge in narrative inquiry. In D. J. Clandinin (Ed.), Handbook of narrative inquiry: Mapping a methodology (pp. 224-245). Thousand Oaks, CA: Sage Publications.

Bean, J. P., \& Metzner, B. S. (1985). A conceptual model of nontraditional undergraduate student attrition. Review of Educational Research, 55(4), 485-540.

Becker, F. S. (2010). Why don't young people want to become engineers? Rational reasons for disappointing decisions. European Journal of Engineering Education, 35(4), 349-366.

Benshoff, J. M., \& Lewis, H. A. (1992). Nontraditional college students. ERIC Digest ED347483.

Berkner, L., Cuccaro-Alamin, S., \& McCormick, A. (1996). Descriptive summary of 1989-90 beginning postsecondary students: Five years later (NCES 96-155). Washington, D.C.

Berkner, L., He, S., \& Catadli, E. (2002). Descriptive summary of 1995-1996 Postsecondary students: Six years Later (NCES 2003-151). Washington, D.C.: U.S. Government Printing Office.

Bye, D., Pushkar, D., \& Conway, M. (2007). Motivation, interest, and positive affet in traditional and nontraditional undergraduaate students. Adult Education Quarterly, 57(2), 141-158.

Chen, X., \& Weko, T. (2009). Stats in Brief: Students who study science, technology, engineering, and mathematics (STEM) in postsecondary education (NCES 2009-161). National Center for Education Statistics, U.S. Department of Education. Washington, D.C.

Choy, S. (2002). Findings from the Condition of Education, 2002. Nontraditonal undergraduates (NCES 2002012). National Center for Education Statistics, Washington, D.C.: U.S. Government Printing Office.

Clandinin, D. J. (2013). Engaging in Narrative Inquiry. Walnut Creek, CA: Left Coast Press.

Clandinin, D. J., \& Connelly, F. M. (2000). Narrative inquiry: Experience and story in qualitative research. San Francisco, CA: Jossey-Bass.

Conefrey, T. (2001). Sexual discrimination and women's retention rates in science and engineering programs. Feminist Teacher, 13(3), 170-192.

Cross, K. P. (1980). Our changing students and their impact on colleges: Prospects for a true learning society. Phi Delta Kappan, 61(9), 630-632.

Cross, K. P. (1981). Adults as learners: Increasing participation and facilitating learning. San Francisco, CA: Jossey-Bass.

Dewey, J. (1938). Experience \& Education. New York: Simon \& Schuster.

Donaldson, J. F., \& Townsend, B. K. (2007). Higher education journals' discourse about adult undergraduate students. The Journal of Higher Education, 78(1).

Foor, C. E., Walden, S. E., \& Trytten, D. A. (2007). "I wish that I belonged more in this whole engineering group:" Achieving individual diversity. Journal of Engineering Education, 96(2), 103-113.

Gonclaves, S., \& Trunk, D. (2014). Obstacles to success for the nontraditonal student in higher education. Psi Chi Journal of Psychological Research, Winter, 164-172.

Haselgrove, S. (1994). The student experience. Bristol, PA: Open University Press. 
Hesse-Biber, S. N. (2014). Feminist approaches to in-depth interviewing. In S. N. Hesse-Biber (Ed.), Feminist research practice: A primer (pp. 182-232). Los Angeles, CA: Sage Publications.

Horn, L. (1996). Nontraditional undergraduates: Trends in enrollment for 1986 to 1992 and persistence and attainment among 1989-1990 beginning postsecondary students (NCES 97-578) National Center for Educational Statistics, Washington, DC: U.S. Government Printing Office.

Hwang, L. S. (December, 2013). Bridge in a Backpack. Popular Science.

Irizarry, J. (2009). Cultural deficit model. [White paper]. Retrieved from http://www.education.com/reference/article/cultural-deficit-model

Jones, D. J., \& Collier Watson, B. (1990). High risk students in higher education: Future trends. ASHE-ERIC Higher Education Report No. 3. Washington D.C.: The George Washington University, School of Education and Human Development.

Kasworm, C. E. (1990). Adult students in higher education: Myths and realities. Community/Junior College Quarterly, 14, 155-175.

Kenner, C., \& Weinerman, J. (2011). Adult learning theory: Applications to nontraditional college students. Journal of College Reading and Learning, 41(2), 87-96.

Marshall, H., \& Nicolson, P. (1991). Why choose psychology? Mature and other students' accounts at graduation. In J. Radford (Ed.), The choice of psychology (Group of Teachers of Psychology, Occasional Paper No. 12) (pp. 22-29). Leicester, U.K.: British Psychological Society.

McNeill, J. C., Long, R., \& Ohland, M. W. (2014). Getting better with age: Older students achieve higher grades and graduation rates. Paper presented at the IEEE Frontiers in Education, Madrid, Spain.

McNeill, J. C., \& Ohland, M. W. (2015). Pathway, choice of major, and peer economic status of nontraditional students in engineering. Paper presented at the IEEE Frontiers in Education Conference, El Paso, TX.

McNeill, J. C., \& Ohland, M. W. (2016). Entry pathways, academic performance, and persistence of nontraditional students in engineering by transfer status. Paper presented at the IEEE Frontiers in Education Conference, Erie, PA.

Miles, M. B., \& Huberman, A. M. (1994). Qualitative data analysis: An expanded sourcebook. Thousand Oaks, CA: Sage.

Mobley, C., \& Brawner, C. E. (2013). Engineering transfer students' views on orientation and advising. Paper presented at the ASEE Annual Conference \& Exposition, Atlanta, GA.

Mobley, C., Shealy, E. G., \& Brawner, C. E. (2012). Work in progress: Transfer students in engineering: A qualitative study of pathways and persistence. Paper presented at the Frontiers in Education Conference, Seatlle, WA.

Mobley, C., Shealy, E. G., \& Brawner, C. E. (2013). First-generation engineering transfer students: A qualitative study of social and cultural capital. Paper presented at the IEE Frontiers in Educaton Conference, Oklahoma City, Oklahoma.

Morice, P. B. (1990). Recruitment of engineering students in the UK. European Journal of Engineering Education, 15(4), 357-360.

National Academies of Sciences Engineering and Medicine. (2016). In S. Malcolm \& M. Feder (Eds.), Barriers and opportunities for 2-year and 4-year STEM degrees: Systemic change to support students' diverse pathways. Committee on Barriers and Opportunities in Completing 2-Year and 4-Year STEM Degrees. Washington, D.C.: The National Academies Press. doi:10.17226/21739

National Center for Education Statistics (NCES). (2002). The Condition of Education 2002. NCES 2002-025. Washington, DC: U.S. Department of Education, NCES.

National Survey of Student Engagement. (2006). Engaged learning: Fostering success for all students. Retrieved from http://www.nsse.jub.edu

National Survey of Student Engagement Annual Report. (2006). Engaged learning: Fostering success for all students.

Retrieved

from http://nsse.indiana.edu/NSSE_2006_Annual_Report/docs/NSSE_2006_Annual_Report.pdf

Nelson, H. L. (1995). Resistance and insubordination. Hypatia, 10(2), 23-40.

Nyquist, J. D., Manning, L., Wulff, D. H., Austin, A. E., Sprague, J., Fraser, P. K., . . Woodford, B. (1999). On the road to becoming a professor. Change, 31(3), 18-27.

Ogilvie, A. M. (2014). A review of the literature on transfer student pathways to engineering degreees. Paper presented at the ASEE Annual Conference \& Exposition, Indianapolis, IN.

Ogilvie, A. M., Knight, D. B., Borrego, M. J., Fuentes, A. A., Nava, P. A., \& Taylor, V. E. (2015). Transfer Student Pathways to Engineering Degrees: A Multi-Institutional Study Based in Texas. Paper presented at the IEEE Frontiers in Education Conference, El Paso, TX.

Ogilvie, A. M., Knight, D. B., Borrego, M. J., Fuentes, A. A., Nava, P. A., \& Taylor, V. E. (2016). Transfer student pathways to engineering degrees: Progress and preliminary findings from a multi-institutional study. Paper presented at the ASEE Annual Conference \& Exposition, New Orleans, LA. 
Pascarella, E. T., \& Terenzini, P. T. (1998). Studying college students in the 21st century: Meeting new challenges. The Review of Higher Education, 21(2).

Patton, M. (2002). Qualitative research and evaluation methods (3rd ed.). Thousand Oaks, CA.: Sage Publications.

Pawley, A. L. (2013). "Learning from small numbers" of underrepresented students' stories: Discussing a method to learn about institutional structure through narrative. Paper presented at the 120th ASEE Annual Conference and Exposition, Atlanta, GA.

Polkinghorne, D. E. (1988). Narrative knowing and the human sciences. Albany, NY: State University of New York Press.

Polkinghorne, D. E. (1995). Narrative configuration in qualitative analysis. International Journal of Qualitative Studies in Education, 8(1), 5-23.

President's Council of Advisors on Science and Technology (PCAST). (2012). Report to the President. Engage to excel: Producing one million additional college graduates with degrees in science, technology, engneering, and mathematics. Washington, D.C.

Quinnan, T. W. (1997). Adult students "at risk": Culture bias in higher education. Westport, CT: Bergin \&Garvey.

Radford, A., Cominole, M., \& Skomsvold, P. (2015). Web tables-Demographic and enrollment characteristics of nontraditional undergraduates 2011-12 (NCES 2015-025). Washington, D.C.

Richardson, J. T. E., \& King, E. (1998). Adults in higher education: Burden or boon? Journal of Higher Education, 69(1).

Schaefer, L. M., Lessard, S. M., \& Lewis, B. (2017). Engaging in a co-created narrative inquiry research space alongside urban aboriginal youth: Pedagogical implications for preservice teachers. Paper presented at the American Educational Research Association Annual Meeting, San Antonio, TX.

Scott, L. M., \& Lewis, C. W. (2012). Nontraditional college students: Assumptions, perceptions, and directions for a meaningful academic experience. The International Journal of Interdisciplinary Social Sciences, $6(4), 1-10$.

Shealy, E. G., Brawner, C. E., Mobley, C., \& Layton, R. A. (2013). A descriptive study of engineering transfer students at four institutions: Comparing lateral and vertical transfer pathways. Paper presented at the ASEE Annual Conference \& Exposition, Atlanta, GA.

Sullivan, M. D., de Cohen, C. C., Barna, M. J., Orr, M. K., Long, R. A., \& Ohland, M. W. (2012). Understanding engineering transfer students: Demographic characteristics and educational outcomes. Paper presented at the IEEE Frontiers in Education Conference, Piscataway, NJ.

Valencia, R. R. (1997). Conceptualizing the notion of deficit thinking. In R. R. Valencia (Ed.), The evolution of deficit thinking, Educational thought and practice (pp. 18-29). London, UK: RoutledgeFalmer.

Wyatt, L. G. (2011). Nontraditional student engagement: Increasing adult student success and retention. The Journal of Continuing Higher Edcuation, 59(1), 10-20.

Zacharakis, J., Steichen, M., Diaz de Sabates, G., \& Glass, D. (2011). Understanding the experiences of adult learners: Content analysis of focus group data. Adult Basic Education and Literacy Journal, 5(2), 84-95.

\section{Author Information}

Angela Minichiello

Department of Engineering Education

Utah State University

4160 Old Main Hill Logan, Utah 84322

U.S.A.

Contact e-mail: angie.minichiello@usu.edu 